\title{
Implementation of The RAD Method to Build an Android-Based Garbage Recycling Application
}

\author{
Fatmariani \\ PalComTech Polytechnic, Indonesia \\ fatma_r@palcomtech.ac.id
}

Submitted : Feb 1, 2022 | Accepted : Feb 7, 2020 | Published : Feb 10, 2022

\begin{abstract}
Garbage is a leading problem polemic that always exists in the surrounding environment, with the amount of garbage the more pollution that causes disasters, one of which is flooding. Garbage itself is divided into organic waste and nonorganic waste. Organic waste itself can be processed into compost, while nonorganic waste can be recycled, one of which is handicrafts. The purpose of this research is to create an android-based application that is used to provide information and procedures for recycling waste. The method used is RAD, namely planning, design, and implementation. The results obtained in this study are an application that contains information that can be used by the community in recycling waste.
\end{abstract}

Keywords: waste recycling, android application, RAD

\section{INTRODUCTION}

Waste is defined as a form of solid waste originating from human activities and then disposed of because it is no longer useful or unwanted. Garbage is a leading problem polemic that always exists in the surrounding environment, with the amount of waste increasing and pollution causing disasters, one of which is flooding. Garbage itself is divided into organic waste and non-organic waste. Organic waste itself can be processed into compost, while organic waste can be recycled, one of which is handicrafts. The purpose of this research is to create an android-based application that is used to provide information and procedures for recycling waste. The community can use this application to find information about waste treatment that is suitable for their condition so that the community can better deal with the existing waste individually.

(Sansprayada, Arfan dan Mariskhana, Kartika., 2020)conducted a study on waste banks, the research resulted in an application where customers and collectors can work together and build partners more broadly and efficiently (Sansprayada, Arfan dan Mariskhana, Kartika., 2020). Purwati, et al also researched environmental waste in 2021, where this research created a website that facilitates sales transactions and services for making environmental waste products (Purwati, Nani, dkk., 2021)Previous research focused on environmental waste management conducted by (Wardhana, W. S., Tolle, H., \& Kharisma, A. P., 2019)in this study only discussed how to manage customer data at the Malang Waste Bank by developing an android-based waste application.

\section{LITERATURE REVIEW}

This study identifies and collects data from several previous studies and is used as a reference in analyzing and compiling this research. Some of the literature reviews used are as follows:

Table 1. Data Analysis Matrix used in the Literature Review

\begin{tabular}{|l|l|l|l|}
\hline No & Researcher & Method & Result \\
\hline 1 & $\begin{array}{l}\text { (Ardi Firmansyah, Muhammad Barja Sanjaya, } \\
\text { dan Patrick Adolf Telnoni, 2016) }\end{array}$ & $\begin{array}{l}\text { Waterfall development } \\
\text { model }\end{array}$ & $\begin{array}{l}\text { This application has } \\
\text { become a solution and } \\
\text { helps to reduce existing } \\
\text { plastic waste by recycling } \\
\text { plastic waste into useful } \\
\text { items so that people are } \\
\text { aware of the importance of } \\
\text { keeping the environment }\end{array}$ \\
\hline
\end{tabular}

*name of corresponding author

This is an Creative Commons License This work is licensed under a Creative

Commons Attribution-NonCommercial 4.0 International License. 


\begin{tabular}{|l|l|l|l|}
\hline & & & $\begin{array}{l}\text { clean and producing items } \\
\text { that are useful for everyday } \\
\text { life. }\end{array}$ \\
\hline 2 & $\begin{array}{l}\text { (Ardi Firmansyah, Muhammad Barja Sanjaya, } \\
\text { dan Patrick Adolf Telnoni, 2020) }\end{array}$ & $\begin{array}{l}\text { SDLC } \\
\text { Development } \\
\text { Cycle) }\end{array}$ & $\begin{array}{r}\text { Sofware } \\
\text { Life }\end{array}$ \\
$\begin{array}{l}\text { The ANGER application is } \\
\text { an application for buying } \\
\text { and selling services } \\
\text { specifically for waste and } \\
\text { garbage used goods and } \\
\text { provide information about } \\
\text { waste and recycling so that } \\
\text { the recyclers recyclers and } \\
\text { collectors or waste } \\
\text { managers can easily get } \\
\text { consumers }\end{array}$ \\
\hline
\end{tabular}

Based on the analysis conducted by the author, the two studies in table 1 are used as a reference in building an android application to produce an application that can be used as a reference for recycling and marketing of recycled products.

\section{METHOD}

The application development method that will be used is the Rapid Application Development (RAD) method. There are three phases in the RAD method involving the analyzer and the user in the stages of assessing, planning, and implementing. The three phases are requirements planning, RAD design workshop (RAD design workshop), and implementation(Pressman, R.G., 2001)The results of the research by Fauzi \& Harli, 2017 show that the RAD method is able to speed up the CRM system development process and can meet the needs of business actors(Fauzi, A., \& Harli, E., 2017)

\section{RESULT}

The implementation of the RAD method to build an android-based waste recycling application was successfully built with the following data:

Table 2. Interview Results

\begin{tabular}{|c|c|c|}
\hline No & Question & Answer \\
\hline 1 & $\begin{array}{c}\text { What are the obstacles faced in the waste } \\
\text { disposal }\end{array}$ & $\begin{array}{c}\text { Garbage accumulation } \\
\text { Garbage rot } \\
\text { Irregular garbage collection }\end{array}$ \\
\hline 2 & What do you think about Waste Recycling & $\begin{array}{c}\text { Recycle waste } \\
\text { Useful for needs }\end{array}$ \\
\hline 3 & $\begin{array}{c}\text { What do you think if there is application } \\
\text { development for waste recycling }\end{array}$ & Can provide new income opportunities \\
\hline
\end{tabular}

a. Plaining stages

Collecting information and data by conducting interviews and documentation studies. In this case, the author conducted interviews with residents (users) and craftsmen of used goods.

The results of interviews and documentation obtained are as follows:

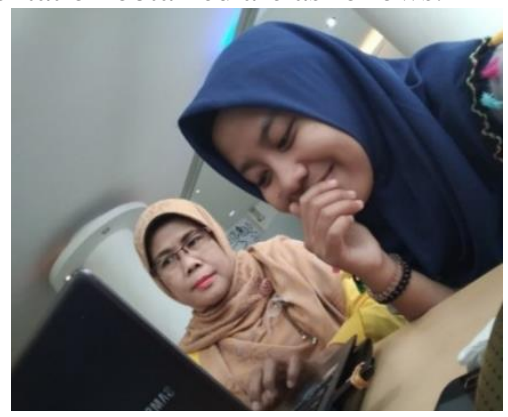

Figure 1. Interview Documentation

b. Design Stage

*name of corresponding author

This is an Creative Commons License This work is licensed under a Creative

Commons Attribution-NonCommercial 4.0 International License. 
The stages of design in this research are to use the use case, activity diagrams, and application design.

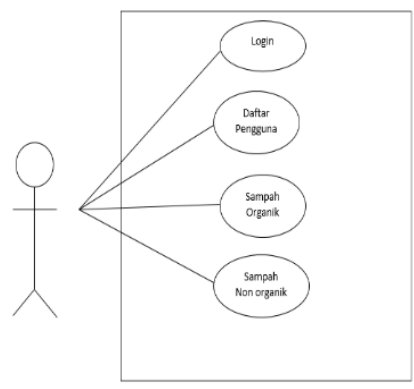

Figure 2. Waste Recycling Application Usecase

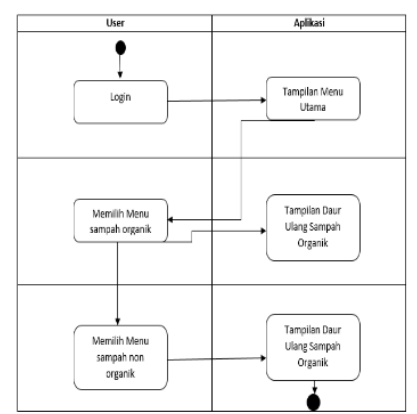

Figure 3. Activity Diagram of Garbage Recycling Applications

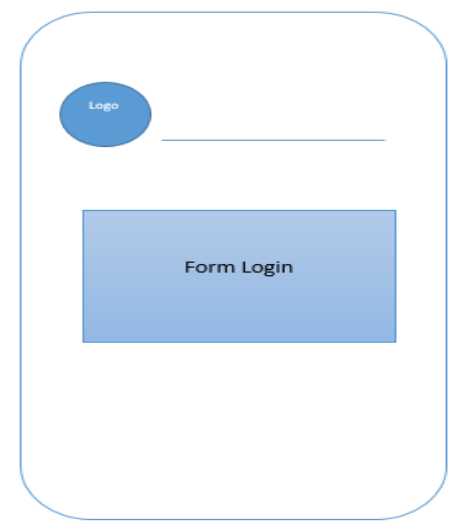

Figure 4. Application login interface design

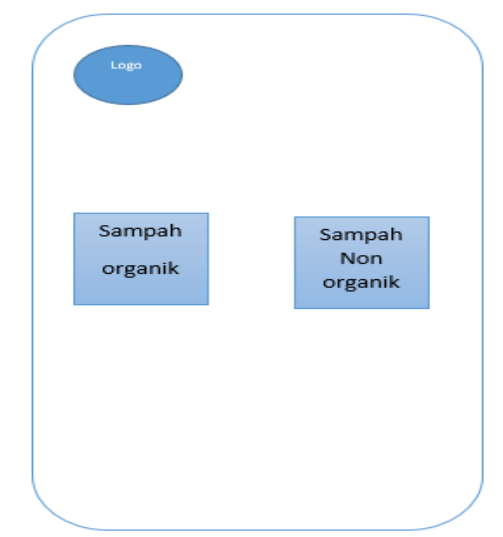

Figure 5. Main Menu Interface Design 


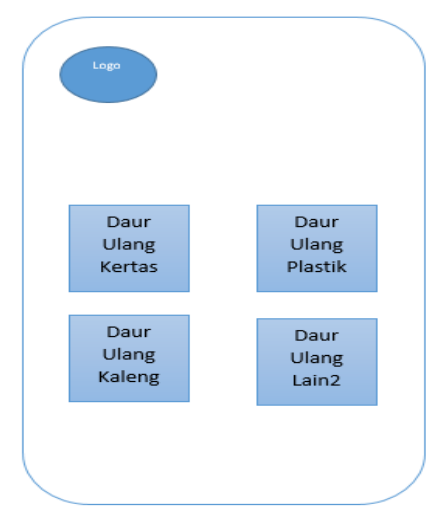

Figure 6. Sub menu interface design

c. Implementation Stages

At this stage, the author analyzes the hardware and software specifications used to run this application properly. The hardware used to design this application is a PC that at least adopts an i3 processor, 8 GB RAM, 2 GB VGA, 250 GB HDD, and Windows 7 OS. 16GB ROM. Then the writing is also looking for Tutorials or Guides for Making Android Applications to help make these applications. The results of the Application Implementation are as follows:

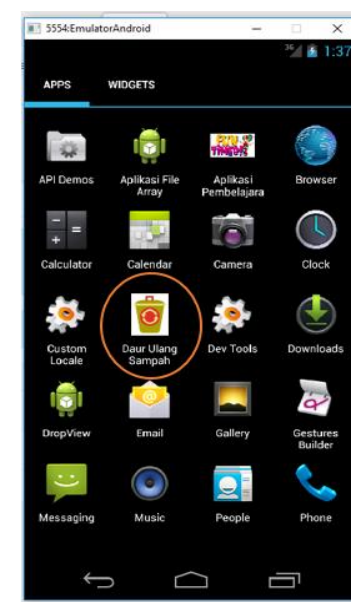

Figure 7. Junk Recycling Apk

The Waste Recycling Apk uses a logo that depicts a trash can and there is a rotating cycle, where it depicts waste that can be recycled, to keep on rotating the cycle.

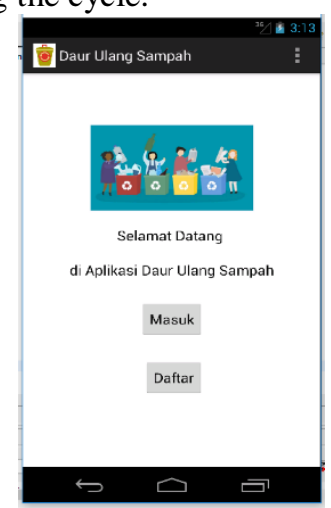

Figure 8. Application Main Page

The main page of the application has two menus, namely the login menu and the register menu, in this application, the login menu is used to log in / enter the application, while the list menu is used for new users who will register and do not have a user and password.

*name of corresponding author 


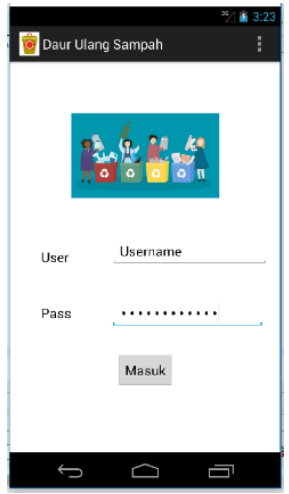

Figure 9. Application Login Display

The initial display of the application contains a form to $\log$ in, where to $\log$ in to the application requires a username and password. The username and password are obtained from the registration process on the application's initial menu.

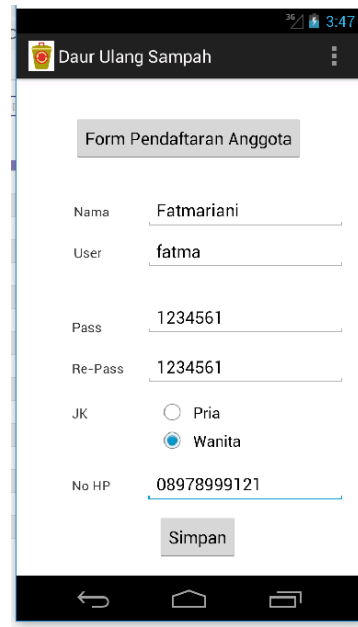

Figure 10. Member Registration Form Display

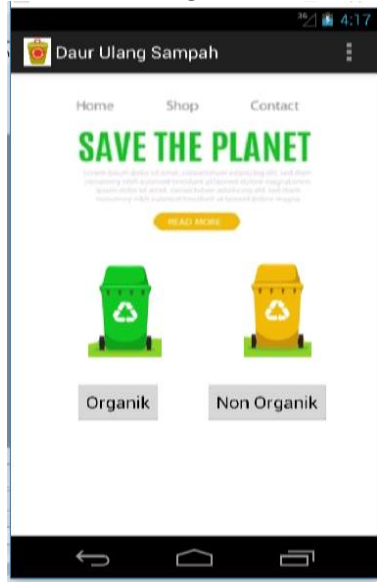

Figure 11. Implementation of the application's main menu

The main menu of the application contains

2 menus, namely organic waste and non organic waste. The recycling process for this waste is different, an explanation of the recycling process is in each submenu of the selected main menu. In this view, there is also a menu for shop and contact. The contents of each menu can be seen in the image below:

*name of corresponding author 


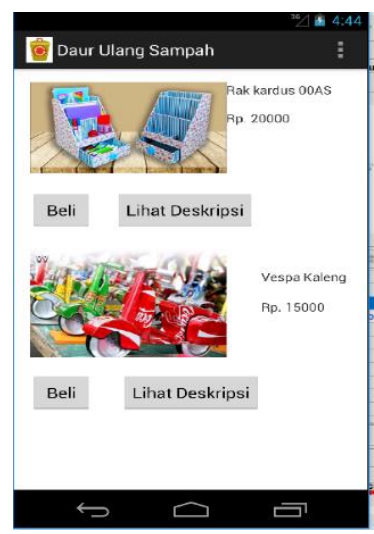

Figure 12. Implementation of the shop menu

The menu shop is used to display recycled processed products, here we can also shop and sell recycled products.

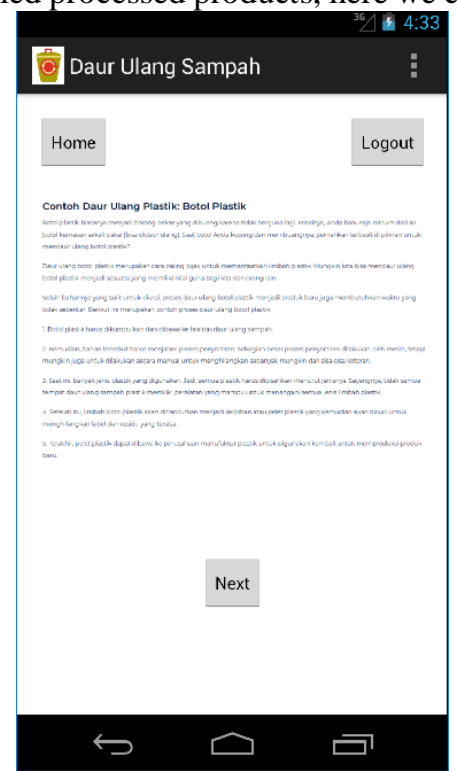

Figure 13. Implementation of the Plastic Recycling Process

The process display contains articles/steps on how to process household waste, the stages, flows, and processes are explained clearly in the application context menu. Here, we will explain the process of recycling waste, starting from the initial stages to the finished product of recycling which has a sale value.

Broadly speaking, this application can be used to guide people in managing household waste, wherewith this application people can pay more attention to the surrounding waste, and can be more useful. This recycling application was tested on users, where the results of application trials obtained the following data:

Table 2. Experiment Results by User

\begin{tabular}{|c|c|c|}
\hline No & Tested questions & Answer \\
\hline 1 & $\begin{array}{c}\text { The interface is more familiar and easy to } \\
\text { use }\end{array}$ & Valid \\
\hline 2 & $\begin{array}{c}\text { The menu can run according to its } \\
\text { function }\end{array}$ & Valid \\
\hline 3 & The login page can be used well & Valid \\
\hline 4 & $\begin{array}{c}\text { Content pages can be read and understood } \\
\text { more easily by the use }\end{array}$ & Valid \\
\hline
\end{tabular}

\section{DISCUSSIONS}

The flow of the waste recycling application is that users can input and publish articles on how to recycle waste. Users can also sell products that will be sold from processed waste recycling in this application. Then the system will save the data to the database so that later it can be displayed in the application where buyers can select and search for items to be purchased. Buyers can buy goods and chat and discuss directly with the seller. This research 
is still limited to the process of recycling waste and marketing to consumers, but this application is still carrying out the buying and selling process through discussion, not yet continued in the buying and selling process carried out in the application. In the action plan, further research will be carried out in the development of this research.

\section{CONCLUSION}

Implementation based on the discussion that has been carried out, this recycling application can run according to its function, and the RAD method can be implemented properly into the Garbage Recycling Android application, from the results of experiments carried out by users, this application is in accordance with the function and is declared valid. and this application can be a solution for the community to be able to recycle their waste, opening up opportunities for community income by selling recycled products to other people. With this application, the community can participate in protecting the natural environment.

\section{REFERENCES}

Ardi Firmansyah, Muhammad Barja Sanjaya, dan Patrick Adolf Telnoni. (2016). Aplikasi Panduan Daur Ulang Sampah Plastik Berbasis Android. e-Proceeding of Applied Science.

Ardi Firmansyah, Muhammad Barja Sanjaya, dan Patrick Adolf Telnoni. (2020). Implementasi Aplikasi Toko Online Ganger untuk Pendaur Ulang Sampah Berbasis Web di Tasikmalaya. JATTEC.

Fauzi, A., \& Harli, E. (2017). Peningkatan Kualitas Pelayanan Melalui CRM dengan Metode RAD. Jurnal RESTI (Rekayasa Sistem Dan Teknologi Informasi), 76.

Pressman, R.G. (2001). Rekayasa Perangkat Lunak 1th Edition. McGrawHill Book Co.

Purwati, Nani, dkk. (2021). Aplikasi Sampling (Sampah Lingkungan) Pengrajin Sampah Berbasis Web Menggunakan Metode RAD (Rapid Application Development). Jurnal Sains dan Manajemen, Vol 1 .

Sansprayada, Arfan dan Mariskhana, Kartika. (2020). Implementasi Aplikasi Bank Sampah BerbasisAndroid Studi Kasus Perumahan Vila DagoTangerang Selatan. Jurnal Inovasi Informatika.

Wardhana, W. S., Tolle, H., \& Kharisma, A. P. (2019). Pengembangan Aplikasi Mobile Transaksi Bank Sampah Online Berbasis Android ( Studi Kasus: Bank Sampah Malang ). Jurnal Pengembangan Teknologi Informasi Dan Ilmu Komputer, 3(7), 6548-6555. 